\title{
Building Student Teacher Interaction Pattern in EFL-CLT Classroom
}

\author{
Mad Riyanto \\ Universitas Muhammadiyah Malang \\ E-mail:mad@yahoo.com
}

Received: July 10, 2018

Accepted: August 17, 2018

Published: August 31, 2018

Doi: http://dx.doi.org/10.30587/jetlal.v2i2.2465

\begin{abstract}
One of the priorities of language teachers is to ensure classes are interesting and engaging. Learners' different backgrounds and individual preferences, however, make each class unique. The objective of EFL classroom adopting Communicative language teaching (CLT) approach is to be fluent and communicative competence in genuine communication (Hatch1978; Nunan, 1987). In this context, EFL teachers play a pivotal role in creating a comfortable environment to persuade the students in communicative interaction. By a good communication between the teacher and students the teaching learning process will be more effective. The teachers can motivate and encourage students to communicate with them well, if interaction has been done. Teachers as the source of second language or foreign language should give meaningful interactions to the students. Krashen(1981,1985) states to facilitate such meaningful interactions, EFL teachers serve as a source of L2 input to the students. The writer attempts to build the pattern of student teacher interaction and reveals the factors inhibit teachers to interact with students.
\end{abstract}

Keywords: Pattern of student teacher interaction, communicative language teaching, communicative interaction

\section{Introduction}

Interaction in teaching learning process is very important, basically, the learners can understand the materials given by the teacher if they have good communication. An effective teacher should try to improve second language classroom and promote learning for doing it. This introductory chapter will explain the pattern of student teacher interaction in EFL classroom, and to reveal the factors inhibit the EFL teachers to promote the communicative interaction with their students in EFL classroom.

The aim of EFL classroom is to support students acquire and develop English language comprehensively. Teachers can teach English in EFL classroom well if they have good interaction with the students. Students' relationship and interaction with teachers either produce or inhibit developmental change to the extent that they engage, meaningfully challenge, and provide social and relational supports (Robert, Bridget, Hamre, and Joseph, 1997). An awareness of the interactional processes can help teachers and learners have a comprehensive understanding of how language is acquires in a formal context (Walsh, 2006). The quality of interaction is determined by teachers in their face to face communication with learners.

Communicative language teaching (CLT) approach is commonly adopted in recent years. Hatch states the priority and key focus in EFL classes adopting CLT is to train up students to be fluent and communicative competent in genuine communication (1978; Nunan, 1987). Managing meaningful student teacher interaction which can promote genuine communication in CLT based class in quite challenging. Despite EFL teacher's efforts of developing learners' communicative capability in real life situation, some research studies reveal that EFL teachers often fail to establish the genuine or natural communication, (Nunan, 1987 p. 137; cited in Seedhouse, 1996; Kumaravadivelu, 1993 p.12). One of the reason is because this kind of interaction requires not only EFL teachers know how technical skills of provide appropriate input (Kraschen, 1981, 1985), various interactional adjustment feedback (Long, 1983, 1985, 1996) or encouragement to students' output (Swain, 1995), but also require the solid quality of the teachers' communicative competence in linguistic, sociolinguistic, discourse, and strategic.

The way they talk and hold the conversation can determine whether EFL teachers can either succeed or fail in implementing their plans (Nunan, 1991). It can give feedback to EFL teachers in general, and then, they can reflect whether their pattern of interaction can promote genuine communication in EFL classroom adopting CLT, and it can give the input the teachers in order to know the pattern of student teacher interaction in teaching English better than before, and and hopefull the readers know further about the pattern of student teacher interaction in teaching English takes a pivotal role in teaching learning process.

\section{Discussion}

The Theoretical Framework

A. The definition of the pattern of student teacher interaction 
Allwright and Kathleen (1991) describe that student teacher interaction has an important role in an effort to develop the students' language. They say that through teacher-student interaction the students can practice the structure of the language being learned and at the same time they understand the meaning. There are four variations of teacher-students interaction: (1) one way-way traffic interaction which is indicated by nonresponse from the students, (2) two-way traffic interaction which is indicated by feedback for the teacher, (3) the interaction indicated by feedback for the teacher, and inter-student interaction, and (4) optimal interaction pattern (Lindgren, 1981).

B. The Function of student teacher interaction

Interaction in teaching learning process of the language can be the goal of developing oral communication. Ellis (1998) states that language development is the result of an interaction between the learner's existing of knowledge (linguistic and conceptual) and the linguistic environment to which he or she is exposed. Erwin-Tripp (1968) considers that the function of interaction is an effect of addressor's action.

Teacher and student interaction is understood to be an important issue in education, and teacher-student interaction is beneficial for students' learning. Flanders (1970) developed an analytical system for teacherstudent interaction and identified seven categories of teachers' behaviors: clarifying feelings, praising, using students' ideas, asking questions, lecturing, giving directions, and criticizing.

C. Communicative language teaching

The teaching learning needs an intensive interaction between the teacher and the students to acquire a second language. It can be effective if the teacher and the student can communicate well each other. People learn languages by interacting, and then learners should interact during lessons. As a result, a method called Communicative Language Teaching (Kathleen, 1991, p.50).

Many various interactional adjustments like asking referential questions, clarifying, checking comprehension and attempting to extend the follow-up turn were much employed. However, whether these kinds of interactional adjustments can lead to genuine communication as suggested by Nunan (1987) was still a question. Similarly to previous studies, negative feedback was the most common interaction category observed and positive evidence on the other hand was the least employed category. Among various negative feedback, implicit negative feedback, especially negotiation moves, were mostly commonly observed. From their verbal interaction pattern, the interaction between the student and the teacher surface show the characteristic of CLT approach since they negotiated the meaning with students. It is seen to extend to feedback, yet, it was not enough. The patterns of interaction implemented in both classrooms were still dominated by typical traditional teacher's classrooms (Thornbury, 1996). This typical pattern of interaction follows restricted IRF (Sinclair \& Coulthard, 1975; Nassaji and Wells, 2000). The teacher made a lot of initiations closed exchange and provided feedback. Students were given a bit chances to response in second turn. This was evidenced by the rarity data of longer students' output.

Factors that can inhibit the EFL teachers to promote communicative interactions are there are differences in between. This is mainly caused by the differences in the teachers and students belief and perception. It is obvious that teachers' belief and perception can be one factor that leads to different teaching practices and verbal interaction pattern. Besides, the EFL teachers' communicative competence can be another factor that determines to what extent they can maintain their interaction with students. The occurrence of negotiation of meaning was proved not the only determinant for the success of student-teacher interaction.

A good EFL teacher should encourage their students' participation in classroom discussion, welcome their contributions, and motivate them by such practices (Cazden, 2001) and facilitate students to produce language output so that they learn to apply the semantic and syntactic processing of the language, thus, they should have qualification to modify the language structures. Reformulating and modifying the students' inappropriate utterances will help students reflect on their mistakes and notice the effect of the use of certain expression on their interlocutors. They will learn from the mistakes to reformulate their non-target-like utterance into more target-like result. This requires the EFL teachers to have language competence that is close to native language proficiency.

\section{Conclusion}

Interaction between the teachers and students has an important role in an effort to develop the students' language. To develop oral communication in teaching learning process of the language need an effective interaction. Teacher-student interaction is beneficial for students' learning. There are seven categories of teachers' behaviors: clarifying feelings, praising, using students' ideas, asking questions, lecturing, giving directions, and criticizing (Flanders, 1970). The teaching learning needs an intensive interaction between the teacher and the students to acquire a second language. It can be effective if the teacher and the student can communicate well each other.

From teachers' verbal interaction pattern, the interaction between the students and the teachers' surface show the characteristic of CLT approach since they negotiated the meaning with students. The differences in the teachers and students belief and perception can be factors that can inhibit the EFL teachers to promote communicative interactions. As 
good EFL teachers should encourage, motivate, and facilitate their students' participation in classroom discussion to produce language output so that they learn to apply the semantic and syntactic processing of the language.

The role of interaction is considered a vital for teaching English as a foreign. The communication between the teachers and the students in teaching learning process is pivotal to get the purpose of study.

\section{References}

Allwright, Dick\&Bailey, Kathleen M. 1991. Focus on the Language Classroom: An introduction to Classroom Research for Language Teacher. London: Cambridge University Press.

Creswell, John W. (2008). Educational Research. Planning, Conducting, and Evaluating Quantitative and Qualitative Research. Pearson International Edition.

Ellis, R. 1988. Modified Oral Input and the Acquisitions of Word Meaning (Applied Linguistic. Rowly, MA: Newbury House).

Erwin Tripp. S. 1968. “An Analysis of Interaction of Language, Topics, and Listener. In Fishman, Y. (Ed) Reading in the Sociology of Language". (The Haque, Mouton.

Kraschen, S.D. Principles and Practice in Second Language Acquisition. New York: Pergamon Press, 1982.

Lindgren, H.C. 1981. Educational Psychology in the Classroom. New York: John Wiley and Sons. Inc.

Long, M. H. and A. P. Porter (1985), "Group Work, Interlanguage Talk, and Second Language Acquisition." TESOL Quarterly, 12,207-228.

Long, M. H. (1996).The role of the linguistic environment in second language acquisition. W. C. Ritchie \& T. K. Bhatia (Eds.). Handbook of second language acquisition. San Diego, CA: Academic Press.

Long, M. H. (1983). Native speaker/non- native speaker conversation and the negotiation of meaning, Applied Linguistics, 4, 126-41.

Long, M. H. (1996). The role of the linguistic environment in second language acquisition. W. C. Ritchie \& T. K. Bhatia (Eds.). Handbook of second language acquisition. San Diego, CA: Academic Press.

Nunan, R. (1999). The purpose of language teachers' questions. International Review of Applied Linguistic, 37, $23-42$.

Robert C, Pianta, Bridget K, Hamre, and Joseph P. Allen. 1997. Teacher-Student Relationship and Engagement; Conceptualizing, Measuring, and Improving the Capacity of Classroom interactions.

Sugiono. 2010. Statistik untuk Penelitian. Bandung: Alfabeta.

Suryabrata, Sumadi. 2006. Metodologi Penelitian. Jakarta: Rajagrasindo Persada

Thornbury Scott. Teachers Research Teacher Talk / ELT Journal 50/40, 1996. pp. 279-290.

Walsh, S. (2006). Investigating classroom discourse. London: Routedge.

Walsh Steve. Construction or Obstruction: teacher talk and learner involvement in the ESL Classroom / Language Teaching Research. Volume 6, Issue 1. January, 2002. pp. 2-23. 